\title{
Quill mites of the subfamily Picobiinae (Acari: Syringophilidae) parasitising African birds, with description of two new species
}

\author{
Miroslava Klimovičová ${ }^{1}$, Maciej Skoracki ${ }^{2}$, Wanyoike Wamitii ${ }^{3}$ and Martin Hromada ${ }^{1,4}$ \\ ${ }^{1}$ Laboratory and Museum of Evolutionary Ecology, Department of Ecology, Faculty of Humanities and Natural Sciences, \\ University of Prešov, Prešov, Slovakia; \\ ${ }^{2}$ Department of Animal Morphology, Faculty of Biology, Adam Mickiewicz University, Poznań, Poland; \\ ${ }^{3}$ Department of Zoology, National Museums of Kenya, Nairobi, Kenya; \\ ${ }^{4}$ Faculty of Biological Sciences, University of Zielona Góra, Zielona Góra, Poland
}

\begin{abstract}
Two new species of the subfamily Picobiinae (Acari: Prostigmata: Syringophilidae) are described: Picobia ploceus sp. n. from Ploceus ocularis Smith (Passeriformes: Ploceidae) and Picobia lamprotornis sp. n. from Lamprotornis superbus (Rüppell) (Passeriformes: Sturnidae), both from Kenya. Additionally, new hosts are recorded: Turdoides jardineii (Smith) (Passeriformes: Leiothrichidae) from Kenya and Tanzania, T. rubiginosa (Rüppell) from Kenya, T. leucopygia (Rüppell) from Zambia and Namibia, for Picobia dziabaszewskii Glowska, Dragun-Damian et Dabert, 2012; Pycnonotus barbatus (Desfontaines) (Passeriformes: Pycnonotidae) from Kenya, for Picobia pycnonoti Glowska, Skoracki et Khourly, 2007; Dendropicos griseocephalus (Boddaert) (Piciformes: Picidae) from Tanzania and D. goertae (St. Müller) from Kenya, for Neopicobia freya Skoracki et Unsoeld, 2014; Dendropicos fuscescens (Vieillot) from Zambia and Campethera nubica (Boddaert) from Kenya, for Picobia dryobatis (Fritsch, 1958).
\end{abstract}

Keywords: Africa, ectoparasites, Ploceidae, quill mites, Sturnidae, taxonomy

Mites of the family Syringophilidae Lavoipierre, 1953 (Acari: Prostigmata: Cheyletoidea) are permanent parasites of birds inhabiting feather quills (Kethley 1970). To date, the family includes more than 300 known species grouped in 59 genera from all zoogeographical regions, except Antarctica (Skoracki et al. 2012). Johnston and Kethley (1973) divided the family in two subfamilies: Picobiinae Johnston et Kethley, 1973 and Syringophilinae Lavoipierre, 1953 (Johnston and Kethley 1973).

Mites of the subfamily Syringophilinae are mostly associated with the quills of flight feather, whereas all members of picobiines inhabit quills of the body feathers (Johnston and Kethley 1973). The subfamily Picobiinae presently comprises of 60 species arranged in nine genera, but taxonomy of this group is still less studied compared to Syringophilinae (see Skoracki et al. 2012). The review of picobiine mites parasitising African birds was conducted by Skoracki and Hromada (2013) and nowadays, only 14 species belonging to four genera from 20 African neognathous hosts are known.

In this paper, we describe two new species of picobiines of the genus Picobia Haller, 1878 from Ploceus ocularis Smith (Passeriformes: Ploceidae) and Lamprotornis superbus (Rüppell) (Passeriformes: Sturnidae), both from Kenya. Additionally, several new African hosts are recorded for picobiines.

\section{MATERIALS AND METHODS}

The material was collected from dry bird skins housed at the National Museums of Kenya, Nairobi, Kenya, and from live trapped birds (using mist netting from 27 October to 2 December 2012) in eight localities in Kenya: Kakamega Forest, Amboseli National Park, Nyahururu, Ndaragwa, Soysambu Conservancy, Naivasha, Njabini and Magumu (research permit NCST/RR1/12/1/203).

A sample of 5-10 body feathers were removed from each dry bird skin of the host. Before mounting, mites were softened and cleared in Nesbitt's solution. In the wild, the samples were removed from trapped birds, which were released back to the wild immediately after sampling. Feathers collected from living birds were placed in $75 \%$ ethanol. In laboratory conditions, the infected quills were dissected; individual mites were removed and mounted on slides in Hoyer's medium. Identification of mite specimens and drawings were carried out with an Olympus BH2 light microscope with DIC optics and camera lucida. Drawings were made with the drawing attachment. All measurements are given in micrometres. Measurements (ranges) of paratypes are given in brackets following data for holotype. In the descriptions below, the idiosomal setation follows Grandjean (1939) as adapted for Prostigmata by Kethley (1990). The nomenclature of leg setation follows that proposed by Grandjean (1944). The morphological terminology follows Skoracki (2011). Scientific names of birds follow Clements et al. (2012). The abbreviations 'NPF' and 'PF' are used for non-physogastric and physogastric form of females, respectively.

Address for correspondence: M. Klimovičová, University of Prešov, 17 Novembra 1, 08001 Prešov, Slovakia. Phone: +421 904895339 ; E-mail: mklimovicova@gmail.com 
Specimen depositories and reference numbers are displayed using the following abbreviations: AMU - Adam Mickiewicz University, Department of Animal Morphology, Poznań, Poland; NMK - National Museums of Kenya, Nairobi, Kenya; LMEE - Laboratory and Museum of Evolutionary Ecology, Department of Ecology, University of Prešov, Prešov, Slovakia.

\section{RESULTS}

Family Syringophilidae Lavoipierre, 1953

Subfamily Picobiinae Johnston et Kethley, 1973

Genus Picobia Haller, 1878

Picobia ploceus sp. n.

Figs. 1, 2

Physogastric female (holotype). Body worm-shaped. Total body length 835 (915-965 in two paratypes).

Gnathosoma. Hypostomal apex rounded, without shoulders. Infracapitulum apunctate. Each medial branch of peritremes with 3-4 chambers, each lateral branch with 5-6 chambers. Stylophore 155 (165) long.

Idiosoma. Propodonotal shield divided longitudinally into 2 narrow, apunctate lateral shields, each bearing bases of setae ve, si and se. Setae ve situated anterior to level of setae vi. Setae vi, ve and si beaded. Setae $c 1$ situated anterior to level of setae se. Setae $d 1$ situated closer to $d 2$ than to $e 2$. Pygidial shield well developed, punctate around setal bases $f 2$. Alveoli of setae $3 a$ not coalesced. Agenital setae $a g l$ situated slightly posterior to level of setae ag2. Genital plate present, punctate near bases of setae $p s 1$ and $p s 2$. Pseudanal setae $p s 1$ and $p s 2$ subequal in length. Genital setae hair-like. Genital lobes absent. Coxal fields I and II well sclerotised and apunctate, III and IV weakly sclerotised and apunctate. Setae $3 c 5.3 \times$ longer than $3 b$.

Legs. Antaxial and paraxial members of claws unequal in size and shape. Setae $t c$ ' and $t c$ " of legs III and IV subequal in length. Lengths of setae: vi (120-140), ve 110 (115-130), si 150 (160-175), se 230 (225-245), c1 200 (240-250), c2 200 (205-215), d1 150 (130-150), d2 170 (165-185), e2 85 (100), fl (35),f2 (40-45), h1 40 (25-30), h2 (275-280), ps1 30 (25-30), ps2 30 (30), gl 15 (15), ag1 80 (80), ag2 (45-50), ag3 115 (125-130), l'RIII 20 (20-25), tc'III-IV 50 (40-45), tc' III-IV 50 (60-65), 3b 20 (20), 3c 105 (105-120).

Male. Unknown.

Type host: Ploceus ocularis Smith (Passeriformes: Ploceidae).

Type locality: Kenya, Soysambu Conservancy $\left(0^{\circ} 24^{\prime} 42^{\prime \prime S}\right.$; 36² 15'3"E, elev. $1857 \mathrm{~m}$ a.s.1.), 16 November 2012, coll. W. Wamiti.

Type material: Female holotype and two female (PF) paratypes. All material is deposited in the AMU (Reg. No. AMU-SYR.607).

Ety mology: The specific epithet (a noun in apposition) refers to the generic name of the host-Ploceus.
Differential diagnosis. This new species is similar to Picobia passeri Skoracki et Sikora 2014, described from Passer domesticus (Linnaeus) (Passeriformes: Passeridae) from Russia (Skoracki and Sikora 2014). In females of both species, the infracapitulum is apunctate; the propodonotal shield is divided longitudinally into two narrow lateral shields bearing bases of setae ve, si and se; setae $v e$ are situated anterior to the level of setae $v i$; setae $c l$ are situated anterior to the level of setae $s e$; the pygidial shield is well sclerotised; the alveoli of setae $3 a$ are not coalesced to each other; the genital plate is present; genital setae are hair-like, and tarsal claws of legs III and IV are unequal in size and shape.

The both species are distinguished as follows: in females of $P$. ploceus, the hypostomal apex is without hypostomal protuberances; each lateral branch of the peritremes is with 5-6 chambers; the pygidial shield is punctate around setal bases $f 2$; the genital plate is punctate near bases of setae $p s 1$ and $p s 2$; agenital setae $a g 1$ are situated slightly posterior to the level of setae ag2; the genital lobes are absent; all coxal fields are apunctate; setae $3 c$ are 5.3 times longer than $3 b$. In females of $P$. passeri, the hypostomal apex bears a pair of protuberances; each lateral branch of the peritremes is with seven chambers; the pygidial and genital shields are apunctate; agenital setae $a g 1$ are situated anterior to the level of setae $a g 2$; the genital lobes are present; the coxal fields I and II are densely punctate, III and IV are apunctate; setae $3 c$ are four times longer than $3 b$.

\section{Picobia lamprotornis sp. $\mathrm{n}$.}

Figs. 3-5

Physogastric female (holotype). Body worm-shaped outline, 1130 long (880-885 in two paratypes).

Gnathosoma. Hypostomal apex rounded, with pair of small shoulders. Infracapitulum apunctate. Each medial branch of peritremes with 4 chambers, each lateral branch with 8 clearly visible chambers. Stylophore 195 (195-200) long.

Idiosoma. Propodonotal shield divided into 2 narrow lateral shields and small oval and punctate medial shield. Setae $v i$ and ve situated at same transverse level. Setae cl situated anterior to level of setae se. Propodonotal setae $v i$, ve and si strongly beaded, other propodonotal and hysteronotal setae lightly ornamented. Setae $d 1$ situated equidistant between setae $d 2$ and $e 2$. Pygidial shield well developed, rarely punctate. Setae $h 11.4 \times$ longer than $f 1$. Alveoli of setae $3 a$ not coalesced. Agenital setae agl situated anterior to level of setae ag2. Genital plate present, apunctate. Genital setae situated on small, rounded genital lobes. Pseudanal setae ps $21.3 \times$ longer than $p s 1$. Coxal fields I and II well developed, apunctate, fields III and IV weakly developed, apunctate.

Legs. Antaxial and paraxial members of claws subequal in size and shape. Setae $t c$ "' of legs III and IV slightly longer $(1.2 \times)$ than $t c ' I I I-I V$. Lengths of setae: ve 95 

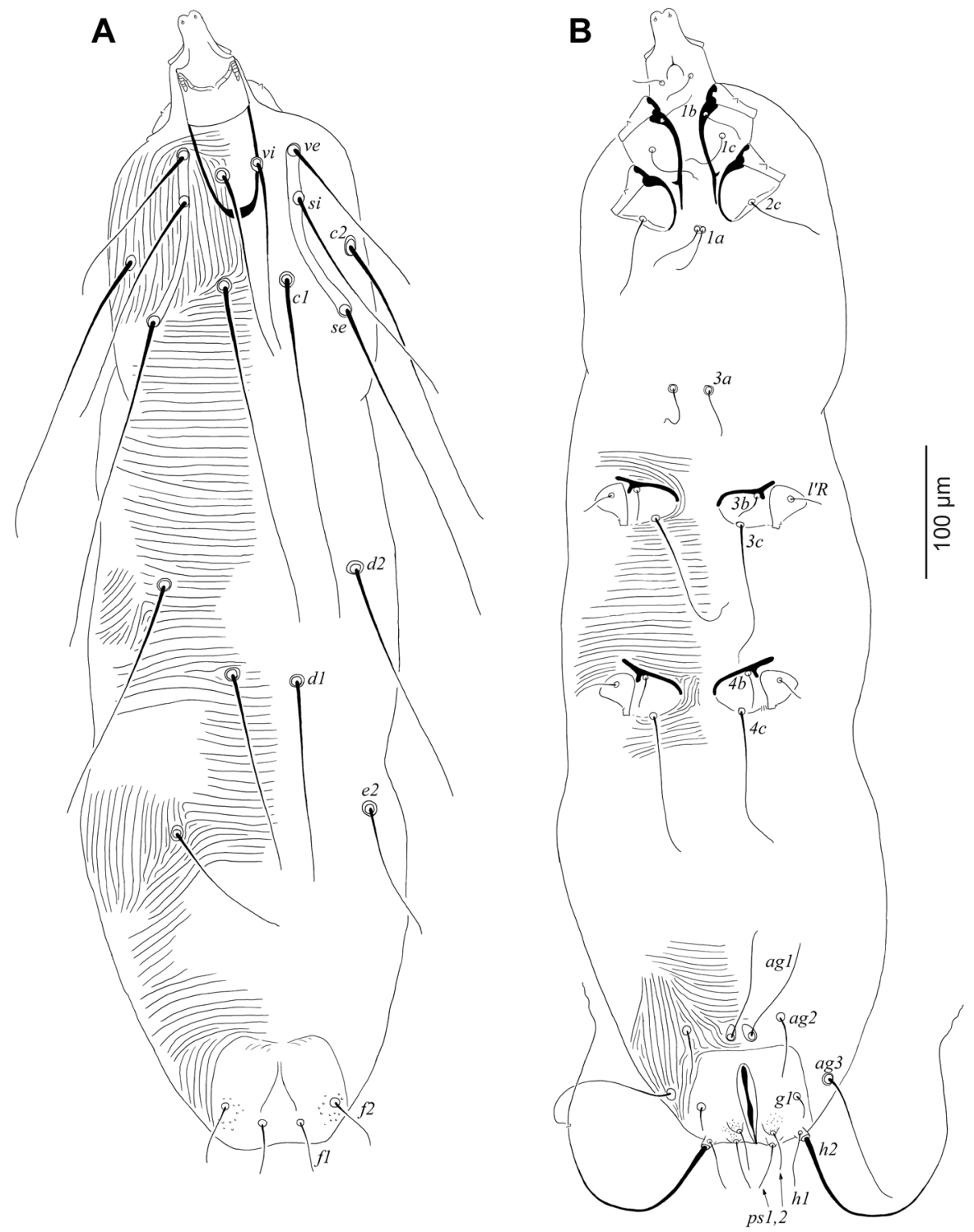

Fig. 1. Picobia ploceus sp. n. from Ploceus ocularis. Female. A - dorsal view; B - ventral view.
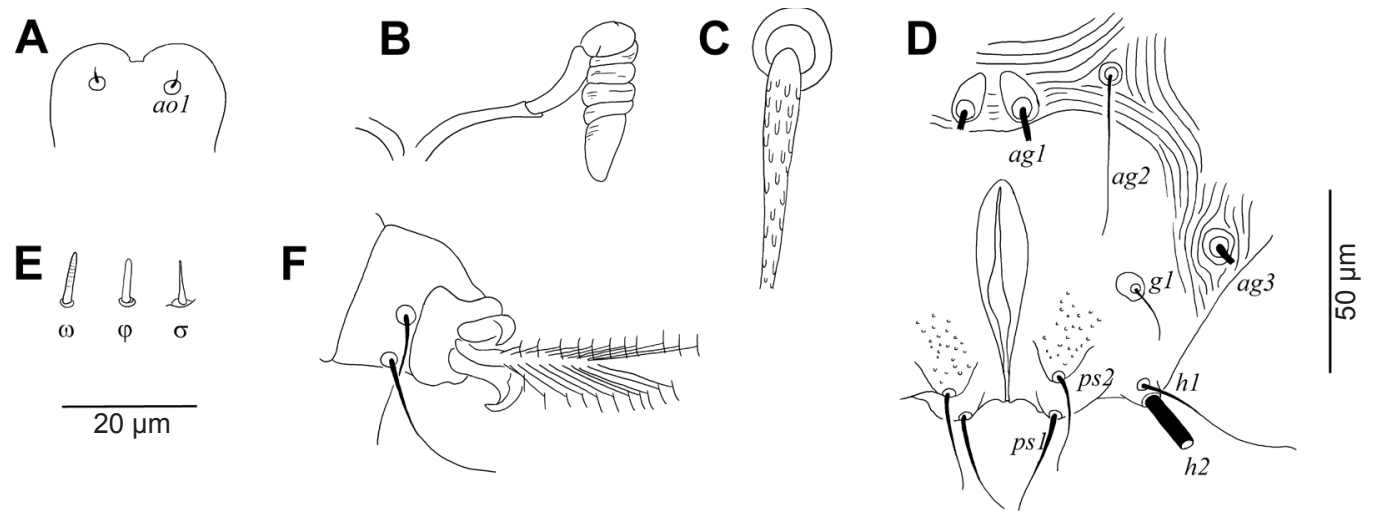

Fig. 2. Picobia ploceus sp. n. from Ploceus ocularis. Female. A-hypostome; B - peritreme; C - propodonotal setae vi; $\mathbf{D}$ - opisthosoma in ventral view; $\mathbf{E}$ - solenidia of leg I; F - tarsus III in ventral view. Scale bar $(20 \mu \mathrm{m})$ for A-C,E,F. 


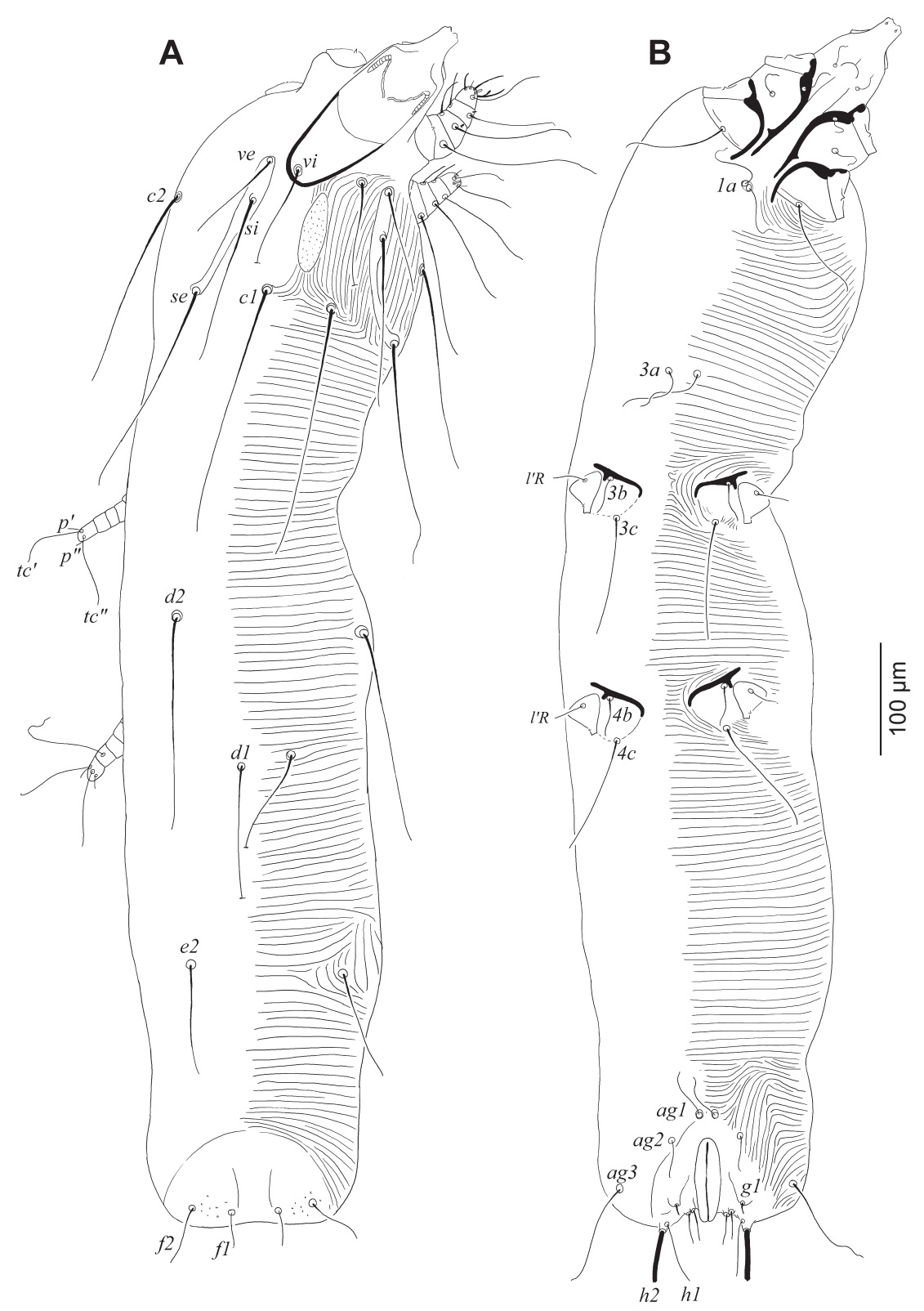

Fig. 3. Picobia lamprotornis sp. n. from Lamprotornis superbus. Female: A - dorsal view, B - ventral view.

(90), si (150), se (190), c1 215 (230), c2 175 (180), d2 (165-190), e2 100 (95-100), f1 35 (35), f2 (50), h1 50 (30-45), ps1 20 (25-30), ps2 25 (25), ag1 (40-45), ag2 30 (30-35), ag3 90 (65-70), l'RIII (30), l'RIV (20), tc'IIIIV 55 (45-50), tc"'III-IV 65 (60-65), $3 b 30$ (30-35), 3c 100 (70-90).

Male (two paratypes). Total body length 455-480.

Gnathosoma. Infracapitulum punctate. Hypostomal apex slightly tapering. Each medial branch of peritremes with 3-4 chambers, each lateral branch with 7-8 chambers.

Idiosoma. Propodonotal shield divided longitudinally into two narrow shields, bearing bases of setae ve, si, se and single median shield, all sclerites punctate. Setae ve situated slightly anterior to level of setae vi. Propodonotal setae $v i$, ve and si lightly ornamented. Length ratio of setae vi : ve : si 1.1-1.2: $1: 1.2-1.3$. Setae $c 1$ located anterior to level of setae se. Hysteronotal shield entire, not fused to pygidial shield, punctate, bearing bases of setae $d 1$ and $e 2$. Setae $d 1$ situated closer to $e 2$ than to $d 2$. Pygidial shield well developed, apunctate. Alveoli of setae $3 a$ not coalesced. Two oval agenital plates, lightly punctate or apunctate, bearing bases of setae $a g 1$ on posterior margin. Setae ag1 $1.8 \times$ longer than ag2.

Legs. Setae 3c 1.8-2× longer than $3 b$. Coxal fields I and II well developed, apunctate, III and IV weakly developed, slightly punctate. Lengths of setae: vi 100-105, ve 85-90, si 110-120, c1 155-160, c2 120-130, d2 130, 

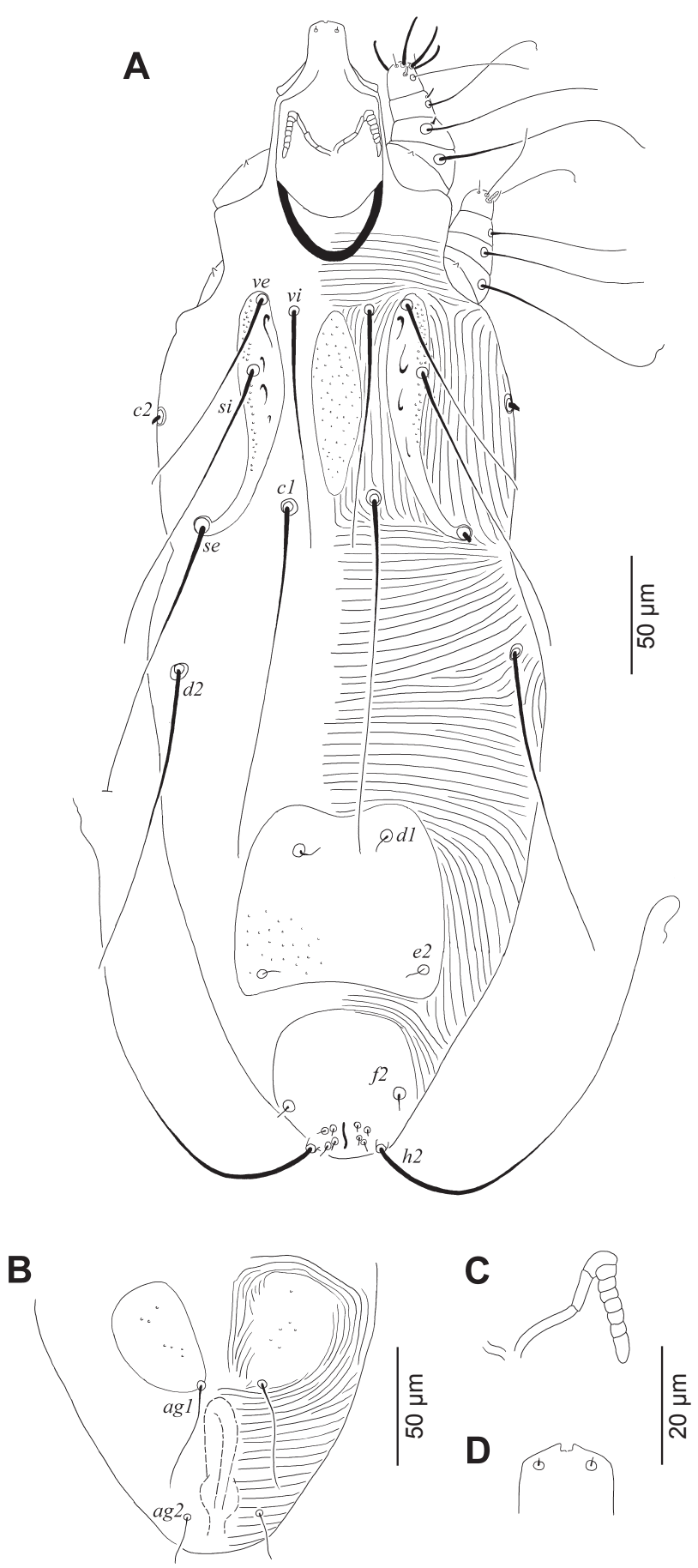

Fig. 4. Picobia lamprotornis sp. n. from Lamprotornis superbus. Male. A - dorsal view, B - opisthosoma in ventral view, C - peritreme, D - hypostome. Scale bar $(20 \mu \mathrm{m})$ for C,D.

e2 5, h2 220,ps1 5, ps2 5, g1 5, g2 5, ag1 35-45, ag2 20, l'RIII 20, tc'III-IV 30-40, tc' III-IV 45, 3b 25, 3c 45-50.

Type host: Lamprotornis superbus (Rüppell) (Passeriformes: Sturnidae)

Type locality: Kenya, Soysambu Conservancy, $\left(0^{\circ} 24^{\prime} 42^{\prime \prime S}\right.$; 36 $6^{\circ} 15^{\prime} 3 " \mathrm{E}$, elev. $1857 \mathrm{~m}$ a.s.1.), 16 November 2012, coll. W. Wamiti.
Type material: Female holotype (PF), two female (PF) paratypes and two male paratypes. All material is deposited in the AMU (Reg. no. AMU-SYR.462).

E ty mology: The specific epithet (a noun in apposition) refers to the generic name of the host - Lamprotornis.

Differential diagnosis. This new species is morphologically similar to Picobia indonesiana Skoracki et Glowska, 2008, described from Aplonis panayensis (Scopoli) (Passeriformes: Sturnidae) from Indonesia (Skoracki and Glowska 2008). In females of both species, setae $v i$ and ve are situated at the same transverse level; setae $v i$, $v e$ and $s i$ are strongly ornamented; the pygidial shield is well developed and punctuate and agenital setae $a g l$ are situated anterior to the level of setae $a g 2$. These species are distinguished as follow: in females of P. lamprotornis, the central propodonotal shield is oval in outline; agenital setae $a g 1$ are $1.3 \times$ longer than setae $a g 2$; the lengths of setae $h 1$ are 30-50; pseudanal setae $p s 1$ and $p s 2$ subequal in the length; the pygidial shield is rarely punctate (Fig. $5 \mathrm{H}$ ). In females of $P$. indonesiana, the central propodonotal shield is pear-like; agenital setae $a g 1$ are $4.3 \times$ longer than setae $a g 2$; the length of setae $h 1$ is 95 ; pseudanal setae ps 1 are distinctly longer than $p s 2$; the pygidial shield is densely punctate (Fig. 5I).

Picobia dziabaszewskii Glowska, Damian-Dragun et Dabert, 2012

(see Glowska et al. 2012: 59, figs. 1-7)

This species was recently described from Garrulax formosus (Verreaux) (Passeriformes: Leiothrichidae) from a frozen bird specimen housed in the Biozentrum Grindel und Zoologisches Museum Hamburg in the University of Hamburg, Germany (Glowska et al. 2012). Although the authors had no data about original locality for host specimen, this host is distributed in China and Vietnam (del Hoyo et al. 2007). Below we provide three new host records belonging to leiothrichid birds of the genus Turdoides Cretzschmar: T. jardineii (Smith), T. rubiginosa (Rüppell) and T. leucopygia (Rüppell).

Material examined: From Turdoides jardineii (Smith) (Passeriformes: Leiothrichidae): Kenya, Soysambu Conservancy $\left(0^{\circ} 24^{\prime} 41.58^{\prime \prime} \mathrm{S}, 36^{\circ} 15^{\prime} 3.29^{\prime \prime} \mathrm{E}\right.$, elev. $1857 \mathrm{~m}$ a.s.1.), 16 November 2012, coll. W. Wamiti: four females (NPF), three females (PF), one male, all deposited in the AMU (Reg. No. AMU-SYR.446A), except one female (PF) in the NMK (Reg. No. NMKorn.10MH) and one female (NPF) in the LMEE (Reg. No. LMEE/S/1); Tanzania, Old Shinyanga, 18-20 May 1937, coll. unknown: two females (PF), deposited in the AMU (Reg. No. AMU-SYR.446B). From the same host species; Tanzania, Marangu, Moshi, 7 January 1953, coll. unknown: one female (PF), deposited in the (Reg. No. AMU-SYR.446C). From Turdoides rubiginosa: Kenya, Amboseli, Kimana Campsite (2०44'34.17"S, 37²2'34.24"E, elev. 1174 m a.s.1.), 22-24 November 2012, coll. M. Hromada, N. Kahure and P. Mikula: four females (PF) and one male, all deposited in the AMU (Reg. No. AMU-SYR.447), except one female in the NMK (Reg. No. NMKorn.11MH). 

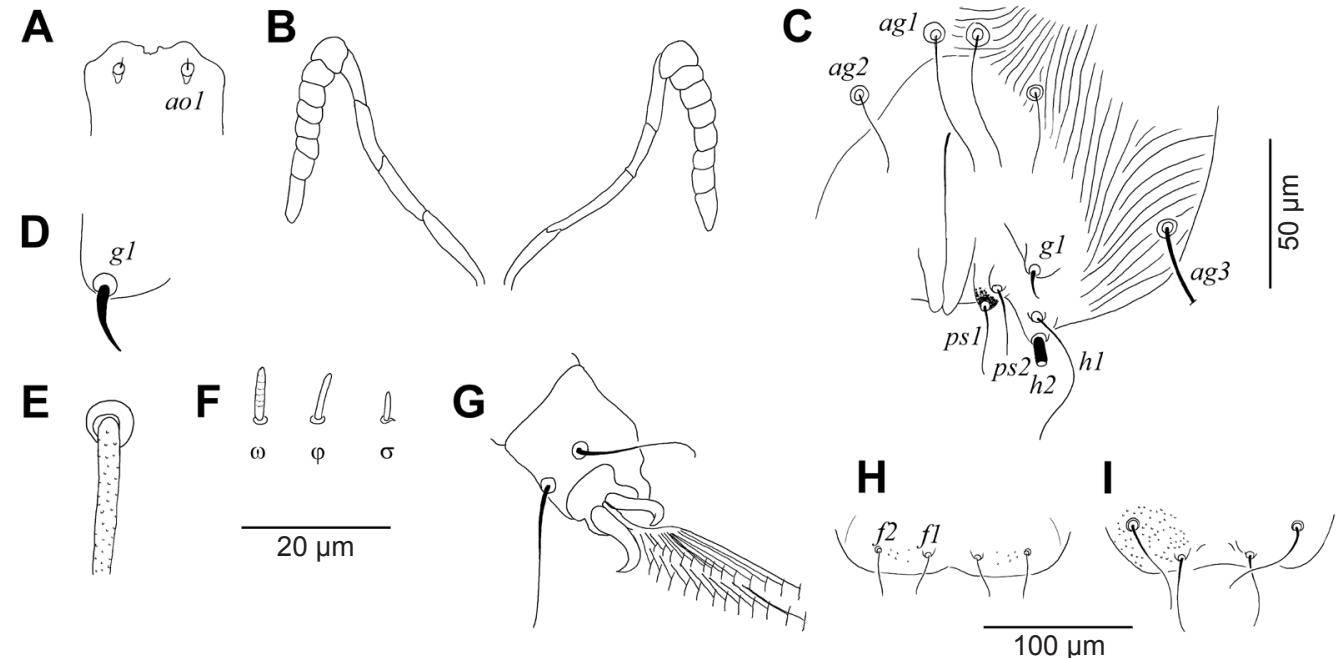

Fig. 5. Picobia lamprotornis sp. n. from Lamprotornis superbus. A-H - Female: $\mathbf{A}$ - hypostome, $\mathbf{B}$ - peritremes, $\mathbf{C}$ - opisthosoma in ventral view, D - genital lobe, $\mathbf{E}$ - propodonotal setae vi, F - solenidia of leg I, $\mathbf{G}$ - tarsus III in ventral view, $\mathbf{H}$ - opisthosoma in dorsal view. I - Picobia indonesiana Skoracki et Glowska, 2008, female; opisthosoma in dorsal view. Scale bar (20 $\mu \mathrm{m})$ for A,B, D-G.

From Turdoides leucopygia: Zambia, Mambova, 11 September 1961, coll. unknown: two females (PF), deposited in the AMU (Reg. No. AMU-SYR.448A). Namibia, Caprivi, 13 October 1954, coll. unknown: one female (PF) and one male, deposited in the AMU (Reg. No. AMU-SYR.448B).

Picobia pycnonoti Glowska, Skoracki et Khourly, 2007 (see Glowska et al. 2007: 64, figs. 1-7)

This species was described from a pycnonotid host species Pycnonotus xanthopygos (Hemprich et Ehrenberg) from Jordan (Glowska et al. 2007), and there have been no other records of this species to this time. Below we present a new host record representing the same genus - Pycnonotus barbatus (Desfontaines).

Material examined: From Pycnonotus barbatus (Passeriformes: Pycnonotidae): Kenya, Nyandarua (Njabini), (044'36.27"S, 36³9'57.14"E, elev. 2524 m a.s.1.), 22 November 2012, coll. W. Wamiti: one female (NPF), deposited in the AMU (Reg. No. AMU-SYR.449).

Neopicobia freya Skoracki et Unsoeld, 2014

(see Skoracki et al. 2014: 74, figs. 4-6)

This species has recently been described from Dryocopus galeatus (Temminck) (type host) from Paraguay and Colaptes rubiginosus (Swainson) from Panama (Piciformes: Picidae) (Skoracki et al. 2014). Two new hosts for this species, Dendropicos griseocephalus (Boddaert) and D. goertae (St. Müller), are provided below.

Material ex a mined: From Dendropicos griseocephalus (Piciformes: Picidae): Tanzania, Shume, 10 January 1933, coll. unknown: four females (NPF) all deposited in the AMU (Reg. No. AMU-SYR.464A), except 1 female in the NMK (Reg. No. NMKorn.13MH); Tanzania, Ngorongoro, 18 July 1966, coll. unknown: one female (NPF), deposited in the AMU (Reg. No. AMU-SYR.464B). From Dendropicos goertae (Picidae): Kenya, Naivasha, 26 March 1939, coll. unknown: three females (NPF), all deposited in the AMU (Reg. No. AMU-SYR.463), except one female in the NMK (Reg. No. NMKorn.12MH).

Picobia dryobatis (Fritsch, 1958)

(see Fritsch 1958: 242, fig. 10 - Syringophilus dryobatis, Kethley 1970: 65; Skoracki 2011: 334, figs. 245-247Picobia dryobatis)

This species is known from several host species belonging to the family Picidae from all zoogeographical regions except Oriental and Australasian (Skoracki et al. 2010, 2012, 2014). Below we report two additional host species, Dendropicos fuscescens (Vieillot) and Campethera nubica (Boddaert) (Piciformes: Picidae).

Material examined: From Dendropicos fuscescens (Piciformes: Picidae): Zambia, Mkushi, 11 July 1957, coll. unknown: five females (NPF) and four females (PF), all deposited in the AMU (Reg. No. AMU-SYR.466), except two females (NPF and PF) in the NMK (Reg. No. NMKorn.16MH) and one female (NPF) in the LMEE (Reg. No. LMEE/S/2). From Campethera nubica (Picidae); Kenya, Sagala Hills, November 1938, coll. unknown: six females (NPF) and six females (PF), all deposited in the AMU (Reg. No. AMU-SYR.465A), except two females (PF, NPF) in the NMK (Reg. No. NMKorn.14MH) and two females (PF, $\mathrm{NPF}$ ) in the LMEE (Reg. No. LMEE/S/3); Kenya, Garissa NFD, 1 May 1943, coll. unknown: two females (NPF) and five females (PF), all deposited in the AMU (Reg. No. AMUSYR.465B); Kenya, Machakos, 10 October 1961, coll. unknown: three females (NPF), six females (PF) and two males, all deposited in the AMU (Reg. No. AMU-SYR.465C), except one female (PF) in the NMK (Reg. No. NMKorn.15MH) and one female (PF) in the LMEE (Reg. No. LMEE/S/4). 
Acknowledgements. We sincerely thank Dr. Idle Farah (Director General), Dr. Muchane Muchai (Head, Zoology Department) and Peter Njoroge (Head, Ornithology Section) at the National Museums of Kenya, for making arrangements to avail of dry bird skins for the present study. We also thank R. Smol'ák, P. Mikula and A. Kahure for assistance with data collection in the field. MK and MH were supported by grants VEGA 1/1244/12 and OPV ITMS26110230119, MK was supported by LLP/Erasmus - student mobility for placement 2013,
MS was financially supported by the Polish Committee for Scientific Research (Grants No. NN303 802540), National Science Centre (Poland) (2011/01/B/NZ8/01749) and by the SYNTHESYS Project (http://www.synthesys.info/), which was funded by the European Community Research Infrastructure Action under FP7 (BE-TAF-1687). MS was also financially supported by the institutional grant FHNS of University of Prešov. WW was financed by the Field Museum of Natural History, Chicago (Irene D. Pritzker Inc. African Training Fund).

\section{REFERENCES}

Clements J.F., Schulenberg T.S., Iliff M.J., Sullivan B.L., Wood C.L., Roberson D. 2012: The eBird/clements checklist of birds of the world: Version 6.7. The Cornell Lab Ornithology, Ithaca, New York, ww.birds.cornell.edu/clementschecklist/downloadable-clements-checklist, 01/2013 (Accessed 15 August 2013).

Fritsch W. 1958: Die Milbengattung Syringophilus Heller, 1880 (subordo Trombidiformes, Fam. Myobiidae Megnin, 1877). Zool. Jahrb. Syst. 86: 227-234.

Glowska E., Dragun-Damian A., Dabert J. 2012: Picobia dziabaszewskii sp. nov. (Acari, Syringophilidae) - combined description (morphology with DNA barcode data) of a new quill mite species parasitizing Garrulax formosus (Passeriformes: Leiothrichidae). Zootaxa 3224: 57-61.

Glowska E., Skoracki M., Khourly F. 2007: A new species and new records of syringophilid mites (Acari: Prostigmata: Syringophilidae) from birds of Jordan. Zootaxa 1635: 63-68.

GRANDJEAN F. 1939: Les segments postlarvaires de l'hysterosoma chez les oribates (Acariens). Bull. Soc. Zool. (France) 64: 273 284.

Grandjean F. 1944: Observations sur les acariens de la famille des stigmaeidae. Arch. sci. Phys. Nat. 26: 103-131.

del Hoyo J., Elliott A., Christie D. 2007: Handbook of the Birds of the World, Vol. 12: Picathartes to Tits and Chickadees. Lynx Edicions, Barcelona, 815 pp.

Johnston D.E., Kethley J.B. 1973: A numerical phenetic study of the quill mites of the family Syringophilidae (Acari). J. Parasitol. 59: 520-530.
Kethley J.B. 1970: A revision of the family Syringophilidae (Prostigmata: Acarina). Contr. Am. Entomol. Inst. 6: 1-76.

Kethley J.B. 1990: Acarina: Prostigmata (Actinedida). In: D.L. Dindal (Ed.), Soil Biology Guide. Wiley and Sons, New York, pp. 667-754.

Skoracki M. 2011: Quill mites (Acari: Syringophilidae) of the Palaearctic region. Zootaxa 2840: 1-415.

Skoracki M., Glowska E. 2008: Two new species of the genus Picobia Haller (Acari: Syringophilidae) from Australian and Indonesian passeriform birds. New Zeal. J. Zool. 35: 281-286.

Skoracki M., Hendricks S.A., Spicer G.S. 2010: New species of parasitic quill mites of the genus Picobia (Acari: Syringophilidae: Picobiinae) from North American birds. J. Med. Ent. 47: 727-742.

Skoracki M., Hromada M. 2013: A review of picobiine mites (Acari: Syringophilidae: Picobiinae) parasitising African birds. Folia Parasitol. 60: 192-212.

Skoracki M., Sikora B. 2014: Two new quill mite species of the family Syringophilidae (Acari: Prostigmata) parasitising the house sparrow Passer domesticus (L.) (Aves: Passeriformes). Zootaxa 3765: 194-200.

Skoracki M., Unsoeld M., Kavetska K., Kaszewska K. 2014: Quill mites of the subfamily Picobiinae (Acari: Syringophilidae) associated with woodpeckers (Aves: Piciformes: Picidae). Acta Parasitol. 59: 68-79.

Skoracki M., Zabludovskaya S., Bochkov A.V. 2012: A review of Prostigmata (Acariformes: Trombidiformes) permanently associated with birds. Acarina 20: 67-107. 